\title{
Ovarian Papillary Cystadenoma
}

National Cancer Institute

\section{Source}

National Cancer Institute. Ovarian Papillary Cystadenoma. NCI Thesaurus. Code C7278.

A serous cystadenoma of the ovary characterized by the presence of small papillary projections in the inner surface of the cysts. 